\title{
What is the Stage of Development of Albania in the Information Society?
}

\author{
Fatos Salliu, PhD Cand. \\ Communication Science, Journalist at TV Klan \& ABC Lecturer of Journalism at \\ "Aleksandër Xhuvani" University in Elbasan. \\ e-mail: tossalliu@gmail.com
}

\section{Abstract}

Information society is a new stage of the social order. It is based on knowledge and offering services on the production of goods. A characteristics of the information society is the quick mass communication development, internet and digital innovation. It creates, distributes, uses and integrates information which is exposed an important economic, political and cultural activity. Ahead to this initiative are the western developed countries. Albania aspires to become part of EU. But in order to achieve this aspiration it should fulfill some standards. This study intends to define in which level toward information society Albania is? If there are implemented the signed agreements with the countries of the Region and EU. If the country is going toward virtual capitalism and which are the concrete steps and problems? So the indicator in this case is measured with the online services offered by the country for its own citizens which are conditioned from the scale of the penetration of internet and digital technology. In order to identify this fact there will be consulted distinguished researchers of the field, specialized monitors, National Strategy document for IT and communication in Albania. At the same time data and statistics from Internet World Stats, and the Agency of the Electronic and Postal Services Agency, Web pages of the Ministries, Prime-Ministers Office, directorates, institutions and agencies dealing with e-services in general, from the Audiovisual Authority of Media, Alexa.com etc. As a conclusion all the data will be compared to the indicators of the EU countries.

Keywords: Information society, Internet, e-services, penetration, active cards.

\section{General concepts on Information Society}

In the post-industrial society, the human society has evolved into the Information Society, with the developed western countries, North America being at the leading edge. Unlike the pre-existing types of society, the main goal of Information Society is to gain competitive advantages in an international level, through the Information Technology (IT), based on creativity and productivity. This type of society, creates, distributes, makes use of, and integrates information, which is subsequently manifested as an important economical, political and cultural activity. These advantages involve rapid and efficient technological, economical, occupational, spatial, cultural changes, or with any combination of such components.

The Information Society is considered as the successor of the Industrial society. Fritz Machlup (1962) introduced the concept of the knowledge economy, as the economic successor of the Industrial society, whereby wealth is created through the economic use/exploitation of understanding. Alain Touraine has defined as the post-industrial society, subsequently the Information society as an area where the cultural reproduction including aspects such as information, consumption, health, research, education would also be industrialized, in the framework of information technology and information services. ${ }^{1}$ For Daniel Bell the number of employed people offering services and information is an indicator for the informative nature of a society. A post-industrial society is based on services. Similarly, post-industrial society has serviced the creative culture...2

Similarly Bell, Peter Otto and Philipp Sonntag (1985) contend that in the Information Society the majority of the working individuals are information-led, so they deal more with information, signals, symbols and images rather than with energy and other issues. ${ }^{3}$ Nico Stehr $(1994,2002$ a, b) asserts that the majority of occupational vacancies involve working with knowledge. ${ }^{4}$ Also Alvin Toffler argues that knowledge is the primary determinant of power and its distribution and

\footnotetext{
${ }^{1}$ Machlup, Fritz (1962) The Production and Distribution of Knowledge in the United States. Princeton: Princeton University Press.

2 Bell, Daniel (1976) The Coming of Post-Industrial Society. New York: Basic Books, 127, 348

3 Otto, Peter/Sonntag, Philipp (1985) Wege in die Informationsgesellschaft. München. dtv

${ }^{4}$ Stehr, Nico (1994) Arbeit, Eigentum und Ëissen. Frankfurt/Main: Suhrkamp. Stehr, Nico (2002a) A World Made of Knowledge. Lecture at the Conference "New Knowledge and New Consciousness in the Era of the Knowledge Society", Budapest, January 31, 2002. Online: [4].
} 
knowledge-production and information-processing is the primary economic activity in the Information society. (Toffler 1994). ${ }^{1}$

In this context, Webster distinguishes chronologically, the various types of the capitalism, respectively: "The capitalism of the 19-th century, the corporative capitalism in the 20-th century, and the Information capitalism of the 21-st century²(Webster 2006). (Christian Fuchs 2008, 2007). "Computer networks are the technological foundation that has allowed the emergence of global network capitalism. These networks are complex due to the high number of nodes (individuals, enterprises, teams, political actors, etc). This segmentation is an expression of the overall competitive character of contemporary society."3(Fuchs 2008: $110+119$ )

High-tech capitalism or informatic capitalism (Fitzpatrick 2002) - to focus on the computer as a guiding technology that has transformed the productive forces of capitalism and has enabled a globalized economy. ${ }^{4}$. Antonio Negri and Michael Hardt argue that contemporary society is an Empire that is characterized by a singular global logic of capitalist domination that is based on immaterial labour. ${ }^{5}$

As steam power was the technology standing behind industrial society, so information technology is seen as the catalyst for the changes in work organization, societal structure and politics occurring in the late 20th century.

In this context, Albania is a developing country that aspires to become a member country of the European Union. Therefore, one of the greatest challenges ahead is keeping pace with the Information society, which is a main feature of the western countries.

\section{The goal and objectives of this study}

The main goal of this study is to define the actual stage of Albania in the Information society. To what extent have the mutual agreements entered between Albania with the Regional and European Union countries, been implemented? Is Albania professing in the virtual capitalism? What are some of the main issues? What measures are taken to solve them?

\section{Hypothesis and methodology}

This study is based on the hypothesis that if Albania as a country makes more efforts towards the improvement of its actual digital technology infrastructure, internet penetration, and especially in the curbing of the "brain drain" phenomenon, then it will manage to keep pace with the rapid technological changes, improve its socio-economical conditions by properly adapting itself in the nowadays Information Society.

The findings of this study are based on the methodology established by various renowned scholars of the field, special monitoring and evaluation studies, on the National Strategy document of the Information Technology and Communication in Albania. They are also supported by various relevant data and statistics retrieved by Internet World Stats, by the Electronic and Postal Control Agency, by the Audio-Visual Media Authority, Alexa.com., etc.

\section{How is Albania implementing its integration strategy in the Information Society? (Analysis and Synthesis)}

Albania has undertaken many reforms in the framework of its aspired membership in the European Union membership. The Europian model of social development is based on knowledge and information society. In this context, since 2002, in Lisbone, Portugal, Albania became one of the signatory member states of the Initiative on the electronic South Eastern Europe (electronic South Eastern Europe), holding the development and use of new technology as a main feature of the rapid social and economical development. ${ }^{6}$.

\footnotetext{
1 Dyson, Esther / Gilder, George / Keyworth, George / Toffler, Alvin (1994) Cyberspace and the American Dream: A Magna Carta for the Knowledge Age. In: Future Insight 1.2. The Progress \& Freedom Foundation.

2 Webster, Frank (2006) Theories of the Information Society. 3rd edition. London: Routledge

3 Fuchs, Christian (2007) Transnational Space and the 'Network Society'. In: 21st Century Society. Vol. 2. No. 1. fq. 49-78. Fuchs, Christian (2008) Internet and Society: Social Theory in the Information Age. New York: Routledge. ISBN 0-415-96132-7.

4 Fitzpatrick, Tony (2002) Critical Theory, Information Society and Surveillance Technologies. In: Information, Communication and Society. Vol. 5. No. 3. fq. 357-378.

${ }^{5}$ Hardt, Michael/ Negri, Antonio (2005) Multitude. War and Democracy in the Age of the Empire. New York: Hamish Hamilton.

${ }^{6} \mathrm{http}: / / \mathrm{www}$.isgtw.org/feature/south-east-european-e-infrastructures-european-2020-vision
} 
In October 2007, Albania reconfirmed its course towards Information society by becoming a signatory member of the sEEE Agenda+ among other South Eastern states. This common Regional agenda was signed in the light of European Union action plan in 2010, on the Information Society. The commitments stipulated in these two documents are rather challenging for Albania, considering its current position in the sector of Information Technology and Communication (ITC).

The National Strategy of ITC was approved through a VKM (Albanian for: Decision of the Council of Ministers/or Executive Order), as of 10.04.2003, which consists of 14 objectives and several measures on the development of the ITC in Albania.. ${ }^{1}$ Such objectives have been partially reached, thus urging for a new strategy to be more responsive to the needs of the reality ahead.

In the recent years substantial progress has been made towards e-governing, enhancing access for business partners through the use of online services, reforms have been implemented in the framework of the improvement of the regulatory regime, businesses registration through the establishment of National Center of Registration (QKR), towards education through the information technology classrooms, information systems set in custom houses, tax offices, etc. Also, a higher level of awareness is observed, on the benefits of the Information Technology and on the extensive use of the internet by businesses, citizens and especially by the younger generation.

The Departmental Strategy for Information Society in Albania from 2008, has until recently been supported by the best models and practices in Europe. Its purpose has been to review and coordinate the obligations Albania has endorsed in the framework of Information Society. The underlying aims to success of this strategy are: the development of Information society in Albania, increasing the use of Information Technology and views the development of information technology infrastructure as the key to a successful implementation of this strategy.

The main fields of the implementation are infrastructure, e-governing and public services, knowledge and education, ebusiness, and the legal framework.

The National Agency of the Information Society is a main central institution established in the Council of Ministers of Albania, and plays an important role in the coordination of policies for the development of the Information society, as well as for the implementation and monitoring of the strategy.

According to the Internet World Statistics, Albania with a population of 3.020.2019 inhabitants, shares the following statistics for 2014: Internet users until 30 June 2014: 1.815 .146 inhabitants. The penetration of internet is $60.1 \%$. Facebook users by 31 December 2012: are 1.097 .800 inhabitants. With a broadband connection downloading speed 7.56 Mbps by September 2014. ${ }^{2}$

With regards to internet use, Albania is ranked lower than Kosovo, Croatia, Bosnia and Macedonia; it is only higher than Serbia, and Montenegro, Bulgaria, and Romania. In the Balkans, the highest rate of Internet use is held by Kosovo, with $76.6 \%$, followed by Croatia with $70.9 \%$, while Facebook në Croatia is used by 1.6 million people. In Bosnia Herzegovina, the penetration of internet reached 67.9\% (with 1.3 million Facebook users); in Macedonia 62.2\% (with 962,000, Facebook users). In Serbia, the penetration of internet was 57\%; in Montenegro 56.8\%, in Bulgaria 53.2\%, and in Romania $49.8 \%$. On the top of the list is Iceland, with an internet penetration of $96.5 \%$; Norway with $95 \%$. Albania makes for only $0.3 \%$ of internet users in the European Union. ${ }^{3}$

\subsection{E-government and e-services}

The e-government has continued as a process of several stages such as information being shared electronically through the world wide web, up to the full transformation of the ways of governing through the offering of online public services, which are secure, reliable, easily accessible and with the active participation of the citizens and businesses. Some of these achievements are:

Electronically shared information has had positive effects in increasing government transparency. The reforms aims against corruption and accountability. In the last 7 years, a much greater importance has been given to the building of the Information society infrastructure, especially to providing the citizens with biometrical ID cards and electronically traceable passports. E-services was powered by the support of organizations such as UNDP and/or European Commission in

\footnotetext{
${ }_{1}^{1}$ http://www.inovacioni.gov.al/files/pages_files/strategjia_versioni_i_printuar_shqip_2.pdf.

$2 \mathrm{http}: / / \mathrm{www}$.internetworldstats.com/stats 4 .htm

$3 \mathrm{http}: / / \mathrm{www}$.internetworldstats.com/stats4.htm
} 
Albania. The government net or GovNet; the ministries and the governmental bodies in Albania, are interconnected through a high speed optical fiber link system. ${ }^{1}$

Such access has made possible governmental activities such as: budget planning, management of the human resources, a transparent judicial reform. All of the ministries have their own internet homepage, populated with all the laws and legal dispositions, news on the activities of each ministry, strategic documents, whereby managing the sharing of information electronically.

This has made possible the electronic publishing in the official notebook of the government of all the legislation; the offering of the electronic information on the criminal record file for the individuals; also the computing and monitoring of the engagements endorsed by the government, in the framework of the integration in the European Union.

With the support of GTZ, ${ }^{2}$ an information system has been set, offering updated information on the agricultural products, in several districts of Albania, but this system does not offer online services for the majority of the rural parts of Albania. Boarder and custom houses operations are also provided electronically. An up-to-date system of information is in place, and provided by the civil registrar offices. ${ }^{3}$

The platform of the electronic procurement is considered as one of the greatest achievements nowadays in Albania, the application is made available via the internet, it is based on automation of the bidding activities. This system makes possible the transactions among the Albanian public institutions and the national and/or international business. The Albanian government has in place a computing system of the public finances. Information on markets, insurance policies, pension schemes, is entered into a special database. The General Tax Directory offers the online (e_filing) of taxes for the legal persons". ${ }^{4}$

A customs electronic system "ASYCUDA++ (Automated System for Customs Data) has also been deployed in Albania, appreciating the benefits in terms of increased revenue, speedy clearance of goods, and the processing of customs declarations in real time. Such a system is operated by all the customs houses in Albania, with the latter being linked to the General Tax Directory network system. Approximately $99 \%$ of the transactions in Albania are made via this system. ${ }^{5}$

In the Health System (e-health), the Management of the Health Statistics Package information system has been applied, by the Ministry of Health in collaboration with ISKSH (Albanian acronym for: The Institute of the Health Care Insurances). 6

In the field of culture (e-culture) all the subordinate departments of the ministry are internet connected. This has made possible the information sharing within the country, and worldwide. Still, much work needs to be done towards identifying, cataloguing, and publishing, as well as information delivering, in order to have a proper exploitation and a better management of the recourses for both locals and tourists alike ${ }^{7}$.

With regards to the employment, obvious progress has been made during the recent years by computing all employment offices, by connecting governmental bodies and businesses online. ${ }^{8}$

From 2008 to 2015, in Albania concrete steps have been taken towards low-cost internet access and use, which is fast and secure. This lowering of costs has been made possible by the high competitiveness of the ISP companies operating in the market. At the same time, there have been implemented projects like Albtelecom, ${ }^{9}$, municipalities offering free wireless connection in the centers of the cities, communes or urban areas, as well as in schools, universities etc.

The mobile telecommunication networks have also launched smart cards, 3-G and 4-G access for the internet and social networks for all the citizens, etc. Thus, it can be contended that the first stage of information sharing via electronic means

\footnotetext{
1 http://www.govnet.net/

2 http://www.tirana.diplo.de/Vertretung/tirana/sq/04/WZ-Projekte/GTZ_Nordalbanien_Seite.html

${ }^{3}$ www.moi.gov.al

${ }^{4} \mathrm{https} / / /$ www.tatime.gov.al/sq-al/us/Drejtoria\%20e\%20P\%C3\%ABrgjithshme\%20e\%20Tatimeve/Pages/default.aspx

${ }^{5} \mathrm{http}: / / \mathrm{www}$. dogana.gov.al/sq/dpd

${ }^{6} \mathrm{http}: / / w w w . i s k s h . c o m . a l /$

7 http://www.kultura.gov.al/

8 http://www.sociale.gov.al/

${ }_{9} \mathrm{http}: / / w w w . a l b t e l e c o m . a l / a l /$ 
has been successfully been completed, and over $50 \%$ of the population (mainly that in the urban area) has already been provided with internet access. Until the end of 2013, public electronic services were offered, based on the best European practices. $^{1}$

The vision of the Albanian governments to build the information society goes hand-in-hand with the regional developments to this direction. By the end of 2014, is observed the standardization of the introduction of internet services by the institutions of all levels. The public services that are offered online are associated with their description and the necessary documents which are downloadable at a mouse-click. The most successful experience in Albania has been the public procurement, avoiding corruption; the latter has been a typical phenomenon in Albania in the years of transition, thus fulfilling one of the main criteria for Albania's integration in the EU.

Public finances on procedures like fund transfer, in all urban areas as well as communes, is being implemented electronically. The General Tax Directory offers all its services online. The customs system performs $100 \%$ of its transactions electronically.

In the Health System, e-health has taken meaningful steps towards improving the quality and efficiency in the Health Care system through the e-health applications. In the avant-garde of this initiative are the private hospitals operating in the country. One of the achievements is 'Telemedicine' which has been installed in several hospital centers.

Another objective that has been fulfilled by the end of 2014, was equipping all schools with IT cabinets, and the ratio 1 computer for 25 students. It has already been integrated in the school curricula of the primary schools, the subject of Information and Communication Technology; also, the curricula of all high/secondary schools have been improved with the integration of ICT subject, in congruence with the European Union standards. During the 2008-2014 period has been completed the training of all ICT (Information Technology and Communication) teachers as well as school administrators, on the teaching of ICT.

The universities and research centers are connected in a high-speed broadband system with many universities of the world. Also, students of different faculties accomplish their internship in the public administration offices.

Information technology and communication, in the recent years have molded new forms of relationship among companies offering goods or services and the customers on the other hand. Meanwhile, special departments fighting cybercrime are already established, in order to allow users a safer internet use. ${ }^{2}$

\subsection{Some other e-services which offered in Albania are:}

Driving license application (driving instruction schools) designated by; my driving license application, my automobiles, my businesses, my income taxes, my family, tracing of cases by protocol numbers, tracing of cases of the National Licensing Center, tracing cases of the public procurement, preliminary application for obtaining a pension, application for electronic excerpts for the citizens, businesses, pension schemes, supplementary pension insurance payments for the military personnel, file transfer or pension eligibility, the automated final high/secondary school examination (a.k.a., matura shteterore), start-up business registration, and other business or personal data, etc. ${ }^{3}$

\subsection{Top searched webpages:}

- $\quad$ Final High School Examination - (Matura Shtetërore)

- Application for Driving License - Aplikim për leje drejtimi (qytetarët)

- Hosting services for web pages - Shërbim hostimi për portale web ${ }^{4}$

The current developments towards offering electronic public services (e-services) show that Albania has taken important steps towards the building of an Information society. However, much work is to be done further in important fields like, Health Care, Agriculture, Industry, Trade, Employment, Culture etc.

\footnotetext{
${ }^{1}$ http://www.inovacioni.gov.al/files/pages_files/strategjia_versioni_i_printuar_shqip_2.pdf

2 http://akshi.gov.al/sherbime.

${ }^{3}$ http://www.e-albania.al/Pages/eServicesList.aspx\#.VLOrA9LF-n0

${ }^{4} \mathrm{http}: / / w w w . e-a l b a n i a . a l / P a g e s / d e f a u l t . a s p x$ 
In the framework of building a more efficient Information society, in order to have a social and economical prosperity, three priorities should be considered: Government-Citizens, Government-Businesses and Government-Government, CitizensCitizens, Citizens-Government, Citizens-Massive Communication. ${ }^{1}$

\section{4 e-Education}

In Albania there are approximately 485,000 in the primary and middle high education and 67.000 students in the high/secondary school education system. There are approximately 2.900 primary schools and $522 \mathrm{high} / \mathrm{secondary}$ schools. There are at least 732 functional ICT cabinets. The digitalization of the all archive registers has already been implemented. In the framework of "Albania in the digital era" motto, the majority of schools nationwide have been equipped with computers Local Area Networks, with internet access, even though this project is unsatisfactory in the schools situated in the countryside, where there is a lack of facilities, infrastructure and internet. ${ }^{2}$

\subsection{Projects on scientific research}

In the context of processes of Euro-Atlantic integration, the academic community is involved in several important regional projects financed by the European Commission. These projects represent an achievement in the development of the European scientific research in the Balkans and its border countries. Tangible examples are projects like SEEREN and SEEREN $2{ }^{3}$ on the connection of national research in the field of Education in the Balkans, with its pan-European academic research network GEANT. ${ }^{4}$

Similarly, projects like SEE_GRID and SEE_GRID2, which aim at the integration and development of the South Eastern European region, aim at having tangible results of the projects implemented in the technological field, GRID, as a main component in the European Research Area (ERA $)^{5}$. GRID technology enables the use of resources through pan-European networks of research in education, through the participation in such virtual European research organizations.

\subsection{Educating the Public and businesses on ICT}

Current developments have increased the number of internet users, indicating among other things an increased awareness of the public appreciating the benefits and the opportunities offered by ICT. From 2008 until 2015 the government has already integrated in the school curricula the subject of ICT. The purpose is for every student to use make use of information and electronic services.

A special emphasis is given to the education on small business companies and partnerships, as in Albania this type of business covers the employing $77 \%$ of the work force. Small companies in Albania, count for $95 \%$ of the total entrepreneurship.

\subsection{Online business and trade}

Electronic business deals mainly with the trade performed electronically, which is a new way that the companies operate through an active use of Information Technology and Communication and through the digitalization process of the businesses in general. Based on an observation performed by IDRA 6 involving around 300 legal individual/large companies, showed that $84 \%$ of the interviewees have full access in their official websites, $68 \%$ of these businesses have high-speed connection.

In the recent years online purchases have become more and more frequent, purchases made by citizens themselves amount to tens millions of Euros a year. In order to have high internet speed and access, Albania has signed its obligations of digital signature, electronic documentation, e-safety, etc. Recently, it has been already approved the Law no. 9880, as of 25.2.2008, "On Electronic Signature" 7

\footnotetext{
1 http://akshi.gov.al/

2 http://www.arsimi.gov.al/

3 http://ICT.upt.al/qkzh.html

${ }^{4}$ http://www.geant.net/Pages/default.aspx

${ }^{5} \mathrm{http}: / /$ ec.europa.eu/research/era/index_en.htm

${ }^{6}$ http://www.idra-al.org/

${ }^{7} \mathrm{http}$ ://akce.gov.al/arkiva/documents/FLETORJA_ZYRTARE_rregullorja.pdf 


\subsection{Internet banking in Albania}

This practice bridges the gaps of the timetables, eliminates procrastination and long queues and other bureaucratic aspects of the traditional banks, allowing a fast and efficient management of personal finances. All banks in Albania offer their services online, providing general information on the bank and the services it offers. ${ }^{1}$

Banks have coordinated their operations with the mobile companies offering services concerning the: information on salaries, bank interests, bank offers, bank credits, invoice payments. The number of electronic cards and credit cards has increased a lot. Also, they are offered with the standards of their mother banks in Europe.

1. Main documents upon which Albania has based its Departmental Strategy for the Development of Information Society 2007-2013, were:

The Joint Declaration of South European Countries signed in the framework of Stability Pact, in June $2002^{2}$

The Agenda for the Development of the Information Society, signed in October 2002:;

The bSEE Memorandum for a bSEE (broadband South Eastern Europe); ${ }^{4}$

The Action Plan of the World Summit on the Information Society; 5

eEuropa Action Plan and the i2010 Initiative of the EU; 6

The National Strategy for Development and Integration 2007-2013 (SKZHI);

The e-SEE plus Agenda, signed in October 2007;

\section{The legal framework for the Information Society}

Albania has signed and continues to compile the legal framework for the achievement of European standards and practices, concerning the development of the Information Society in the country. In the field of cybercrime, Albania has already signed and rectified the Cybercrime Convention ${ }^{9}$ in 2002 , the latter, has also been introduced in the country's Penal Code ${ }^{10}$ also, the requirements of this Convention are stipulated in the Code of Penal Procedure. ${ }^{11}$

\section{The means of mass communication}

The means of mass communication have seen a considerable development during the last 15 years in Albania. Furthermore, several of the digital platforms are as up-to-date as they can be anywhere else in the world.

The market of audio-visual media is managed by AMA (The Authority of AudioVisual Media). This is an independent body which operates based on the dispositions of Law no. 97/2013 as of 04.03.2013.. ${ }^{12}$ One of the significant projects in the recent years is the South-East European Digital Television. AMA has become part of this project 'South-East European Digital Television ${ }^{13}$ (SEE Digi TV)", in the framework of Inter-National Cooperation of South-Eastern Europe Programme, financed by the European Union. ${ }^{14}$

\footnotetext{
${ }^{1}$ http://www.bankofalbania.org/previewdoc.php?crd=3242

$2 \mathrm{http}: / / w w w . a k s h i . g o v . a l / s t r a t e g j i a$

${ }^{3} \mathrm{http}: / /$ www.dap.gov.al/images/Arkiva/SKZHI_2007-2013.pdf

${ }^{4} \mathrm{https}$ ://www.yumpu.com/sq/document/view/15569392/sfida-drejt-nje-shoqerie-te-informacionit-mitik/33

${ }^{5} \mathrm{http}: / / w w w . a k e p . a l /$ informacion/pagesa/283-samiti-boteror-i-shogerise-se-informacionit-wsis 10

${ }^{6} \mathrm{http}$ ://ec.europa.eu/digital-agenda/en/european-egovernment-action-plan-2011-2015

${ }^{7}$ http://www.dap.gov.al/images/Arkiva/SKZHI_2007-2013.pdf

$8 \mathrm{http}: / /$ www.art-ks.org/repository/docs/Politikat\%20e\%20Sektorit\%20te\%20Komunikimeve\%20Elektronike\%20-

\%20Axhenda\%20Dixhitale\%20per\%20Kosoven\%202013-2020.pdf

${ }^{9} \mathrm{http}: / / \mathrm{www}$.infocip.org/al/?p=3655

$10 \mathrm{http}: / /$ www.hidaa.gov.al/ligje/kodi\%20penal\%20i\%20rsh.pdf

$11 \mathrm{http}: / /$ www.pp.gov.al/web/kodi_proc_penale_202.pdf

$12 \mathrm{http}: / /$ ama.gov.al/

$13 \mathrm{http}: / / w w w . s o u t h e a s t-e u r o p e . n e t / e n / p r o j e c t s / a p p r o v e d \_p r o j e c t s / ? i d=124$

$14 \mathrm{http}: / /$ ama.gov.al/index.php?option=com_content\&vieë=article\&id=215\%3Arreth-projektit-digi-tv\&catid=25\%3Atelevisioni-dixhital-ieuropes-juglindore\&lang=sq.
} 
In Albania there is a Public Television (landline and satellite TV), TVSH. Two other privately owned channels, TV Klan and Top Channel TV are also licensed as national TV. There are two satellite privately owned channels: Vizion + and ALSAT. The private numeric satellite platforms are: Digitalb, Tring TV and Supersport.

In Albania there are 71 privately owned television stations and 83 cable TV operators. ${ }^{1}$ Albania has also a periodical of 23 national journals and dozens of local newspapers.

Online media has been progressing at a fast pace during the recent years. Albanians can be considered frequent internet users, at the level of $61 \%$. Blogs, web 2.0, mobile media has also made possible what is known today as citizen journalism and community reporting, due to the social media developments over the last decade or so. According to the Union of Journalists, only during the 2014, 250 sites of citizen journalism were built only for 2014. Albanians do use Facebook a lot, followed by Youtube, Instagram, Twitter, Linkedln, MySpace etc. One of the mostly used search engine is Google, followed by Yahoo.

Newspapers, magazines, radio and television stations have gone online, too. Mobile operators offer alternative live streaming media and their own internet apps, for the "third screen" mobile phone devices.

\subsection{The following is the ranking of Albanian sites according to internet monitoring of Alexa.com}

1. Gazetaexpress.com

2. Telegrafi.com

3. Facebook.com

4. Google.com

5. Google.al

6. Youtube.com

7. Merrjep.com

8. Yahoo.com

9. Balkanweb.com

10. Koha.net ${ }^{2}$

8. The general picture of internet penetration, fixed and mobile telephony in Albania from the year $\mathbf{2 0 1 0}$ until June 2004. (Based on the data published AKEP (Albanian acronym for: Authority of Postal and Electronic Communication $)^{3}$

As above mentioned, the basis for an Information society is the means of massive communication, such as: internet, digital technology, mobile and wireless technology. The number of mobile telephony subscribers' of active SIM cards went to 4.9 million and the number of subscribers measured according to the active mobile users (subscribers who have used their mobile services in the last 3 months) was 3.5 million. The penetration of fixed and mobile telephony was respectively $9.2 \%$ and $123 \%$.

The number of subscribers having fixed and mobile access (using $3 G$ using portable USB/modem) by the end of June reached 324 thousand, which makes for a 10.4\% increase, compared to the end of 2013. Both access broadband network segments, fixed and $3 \mathrm{G}$ (using portable USB/modem) have seen an increase of $3.3 \%$ and $22 \%$ compared to 2013 .

\subsection{The Mobile Telephony Market}

The number of mobile telephony users from 2010 and on, has been monitored by AKEP in two ways, according to the active users and SIM active card users. The number of active users for four mobile companies Plus, Alb (EM), Vodafone and AMC until the end of June 2014 was 3.5 million users and the number of SIM card users 4.9 million. (See figure 1)

\subsection{The fixed telephony Market}

\footnotetext{
1 http://ama.gov.al/index.php?option=com_content\&vieë=category\&id=21\&ltemid=75\&lang=sq.

$2 \mathrm{http}: / / \mathrm{www}$.alexa.com/topsites/countries/AL

3 http://www.akep.al/ 
The number of subscribers in the fixed telephony in the first 6 months of 2014 has decreased by $9.2 \%$, compared to the end of 2013. In Albania the fixed telephony service is offered to 255.358 subscribers against 337.885 , maximum level of subscribers of this service during 2009. ${ }^{1}$ (See figure 2 )

\subsection{The Internet}

The internet service access is offered by both fixed and mobile networks. By the end of the first 6 months of 2014, the number of subscribers having broadband access, has been increased. The number of subscribers in the fixed networks has been 188.668. The fixed network segment access for several operators has been offering this service as the following:

During the first six months of 2014 the number of subscribers with broadband aces via fixed networks had an increase of $3.3 \%$ compared to 2013 , and the majority of operators has the number of their subscribers.

Even the broadband network segment of mobile $3 G$ networks, has had positive developments, whereby the number of subscribers through cards/modems/keys (not mobile portable devices) was increased with $22 \%$ in comparison to the end of 2013. The number of users with $3 \mathrm{G}$ broadband access is approximately 923 thousand, by the first half of 2014 , which is a reduction by $18 \%$ in comparison with 2013. In total, the number of users having broadband $3 G$ access (mobile devices and USB cards), amounts to 1.06 million.

Further detailed information on the network segment of broadband access provided by both networks can be found in figure 3 ; this figure provides a detailed description on the internet penetration in the Albanian families and population. There is a notable increase in internet penetration in both cases. The scale of internet penetration in the Albanian population by both fixed and mobile networks is $11.46 \%$ per 100 inhabitants. As for a given number of families it reaches $45 \%$. Consequently, despite the great progress of the recent years, Albania is still behind the European Union countries in this respect, where the scale, according to World Stats is $70.5 \%$. (See figure 3 )

In the rural areas live $50 \%$ of the population, the scale of internet penetration is much lower than in the city. Due to the lack of fixed telephony, this service is offered only by the mobile telephony companies, but still the form is limited to Gigabytes usage made available, according to the amount of payment.

The ultimate and most frequently used form of communication in Albania remains that of the social networks, which are offered free of charge by these companies. Thus, the "third screen" or "the mobile media" has more advantages than internet in Albania.

\section{The government electronic services in Albania according to a survey made by the United Nations in 2012}

Albania is ranked in the 86-th position, in the South Eastern Europe index for its online government services with a quotient of 0.5161 assessment made in a recent survey carried out by the United Nations in 2002. The online services index and its components according to the same report in Albania is 0.4248 or $37 \%$. As for the infrastructure and telecommunication, Albania's index is 0.3370. (See figure 4)

\section{Albania}

The index of the human capital in Albania is 0.7863 . The index of electronic collaboration is better and Albania comes in the 28-th position along with some other countries having a quotient of 0.1053 . Albania is in the 43-rd place for its environmental index, together with some of the best countries, surpassing countries like Slovakia, Spain, Cyprus, Czech Republic, etc. Albania is not in the list of the European Countries whose web pages are provided with the statement: Follow us on Facebook or twitter. ${ }^{2}$

\section{Conclusions}

1. Albania comes last in the list of 86 South Eastern European countries, concerning the index of government services, according to the survey carried out by the United Nations.

\footnotetext{
1 http://www.akep.al/images/stories/AKEP/statistika/TREGUESIT-STATISTIKORE-6-MUJORII-I-re-2014-301014.pdf

2 http://unpan3.un.org/egovkb/Portals/egovkb/Documents/un/2012-Survey/unpan048065.pdf. 
2. -The Albanian government has taken concrete steps towards the Information Society, but its actual achievements still lag behind the indicators set by the European Union, whereby Albania aspires to join as a member state.

3. -According to the National Agency of Information Society (AKSHI) the public administration in Albania needs to be further sensitized on the use of technology and information, as a part of the e-government process for good governance.

4. There is a need for improving the information and technology infrastructure of the public administration

5. There is a need for increasing the human resources dealing with information and communication technology and providing ongoing qualification. ${ }^{1}$

6. -The availability of E-services (electronic services) and finally m-services (mobile services) are considered as one of the greatest challenges in the development of Information Society in Albania, as well as it's the social and economical development. But in this field, much work remains ahead

7. -The scientific research activities in Albania have been limited due to the lack of infrastructure and the scarce financial resources. A considerable number of specialists have abandoned the scientific research institutes and the majority of them have migrated abroad. -The specialized departments of ICT have suffered a massive "brain drain". For the same reason the public institutions have great difficulties in finding the necessary experts for the everyday maintenance of the ICT infrastructure.

8. -Internet penetration in Albania remains still under the EU norms. The reason for this is the low scale of knowhow on ICT as well as the lack of proper knowledge on the benefits that come with the use of information and communication technology.

9. -According to the monitoring specialists, the internet penetration scale in Albania is $45 \%$ while the average of all the European Countries is $75 \%$.

10. -The 3 and $4 \mathrm{G}$ high speed broadband services are still limited in the more developed urban downtowns. In the rural areas there is a lack of this service which implies that more investments are need in the infrastructure are still to be made by the companies operating in this field, and the situation calls for more strategies and policies in favour of such services.

\section{References}

[1] Bell, Daniel. The Coming of Post-Industrial Society. New York: Basic Books, (1976) pp.127, 348

[2] Dyson, Esther/ Gilder. George/Keyworth, George/Toffler, Alvin: Cyberspace and the American Dream: A Magna Carta for the Knowledge Age. In: Future Insight 1.2. The Progress \& Freedom Foundation. (1994)

[3] Fitzpatrick, Tony: Critical Theory, Information Society and Surveillance Technologies. In: Information, Communication and Society. (2002) , Vol. 5. No. 3. fq. 357-378.

[4] Fuchs, Christian, Transnational Space and the 'Network Society'. In: 21st Century Society. (2007), Vol. 2. No. 1. pp. 49-78.

[5] Christian Fuchs Internet and Society: Social Theory in the Information Age. New York: Routledge. ISBN 0-415-96132-7. (2008)

[6] Hardt, Michael, Negri, Antonio: Multitude. War and Democracy in the Age of the Empire. New York: Hamish Hamilton. (2005)

[7] http://akce.gov.al/arkiva/documents/FLETORJA_ZYRTARE_rregullorja.pdf

[8] http://akshi.gov.al/

[9] http://akshi.gov.al/sherbime.

[10] http://ama.gov.al/index.php?option=com_content\&view=article\&id=215\%3Arreth-projektit-digitv\&catid=25\%3Atelevisioni-dixhital-i-europes-juglindore\&lang=sq 
[11] http://ama.gov.al/index.php?option=com_content\&view=category\&id=21\&ltemid=75\&lang=sq

[12] http://ec.europa.eu/digital-agenda/en/european-egovernment-action-plan-2011-2015

[13] http://ec.europa.eu/research/era/index_en.htm

[14] http://itc.upt.al/qkzh.html

[15] http://unpan3.un.org/egovkb/Portals/egovkb/Documents/un/2012-Survey/unpan048065.pdf

[16] http://www.albtelecom.al/al/

[17] http://www.albtelecom.al/al/mobile/informacion-i-pergjithshem-telefonia-celulare/882-telefonia-celulare

[18] http://www.alexa.com/topsites/countries/AL

[19] http://www.akep.al/

[20] http://www.akep.al/images/stories/AKEP/statistika/TREGUESIT-STATISTIKORE-6-MUJORI-I-re-2014301014.pdf

[21] http://www.akep.al/informacion/pagesa/283-samiti-boteror-i-shoqerise-se-informacionit-wsis10

[22] http://www.akshi.gov.al/strategjia

[23] http://www.art-

ks.org/repository/docs/Politikat\%20e\%20Sektorit\%20te\%20Komunikimeve\%20Elektronike\%20\%20Axhenda\%20Dixhitale\%20per\%20Kosoven\%202013-2020.pdf

[24] http://www.arsimi.gov.al/

[25] http://www.bankofalbania.org/previewdoc.php?crd=3242

[26] http://www.dap.gov.al/images/Arkiva/SKZHI_2007-2013.pdf

[27] http://www.dogana.gov.al/sq/dpd

[28] http://www.e-albania.al/Pages/default.aspx

[29] http://www.e-albania.al/_layouts/Services/Service.aspx?shld=689\#.VLOrUNLF-n0

[30] http://www.e-albania.al/Pages/eServicesList.aspx\#.VLOrA9LF-n0

[31] http://www.geant.net/Pages/default.aspx

[32] http://www.govnet.net/

[33] http://www.hidaa.gov.al/ligje/kodi\%20penal\%20i\%20rsh.pdf

[34] http://www.idra-al.org/

[35] http://www.infocip.org/al/?p=3655

[36] http://www.inovacioni.gov.al/files/pages_files/strategjia_versioni_i_printuar_shqip_2.pdf

[37] http://www.internetworldstats.com/stats4.htm

[38] http://www.isgtw.org/feature/south-east-european-e-infrastructures-european-2020-vision

[39] http://www.isksh.com.al/

[40] http://www.kultura.gov.al/

[41] http://www.pp.gov.al/web/kodi_proc_penale_202.pdf

[42] http://www.projektiqytetar.org/gtz.php 
[43] http://www.qkl.gov.al/

[44] http://www.sociale.gov.al/

[45] http://www.southeast-europe.net/en/projects/approved_projects/?id=124

[46] https://www.tatime.gov.al/sqal/us/Drejtoria\%20e\%20P\%C3\%ABrgjithshme\%20e\%20Tatimeve/Pages/default.aspx

[47] http://www.tirana.diplo.de/Vertretung/tirana/sq/04/WZ-Projekte/GTZ_Nordalbanien_Seite.html

[48] https://www.yumpu.com/sq/document/vieë/15569392/sfida-drejt-nje-shoqerie-te-informacionit-mitik/33

[49] Machlup, Fritz: The Production and Distribution of Knowledge in the United States. Princeton: Princeton University Press. (1962)

[50] Otto, Peter/Sonntag, Philipp: Wege in die Informationsgesellschaft. München. Dtv (1985)

[51] Stehr, Nico: Arbeit, Eigentum und Wissen. Frankfurt/Main: Suhrkamp. (1994)

[52] Stehr, Nico: A World Made of Knowledge. Lecture at the Conference "New Knowledge and Neë Consciousness in the Era of the Knowledge Society", Budapest, January 31, 2002a. Online: [4]

[53] Webster, FrankTheories of the Information Society. 3rd edition. London: Routledge. (2006)

[54] www.moi.gov.al

\section{Figures}

Figure 1 Mobile telephony performance during 2010-2014 period

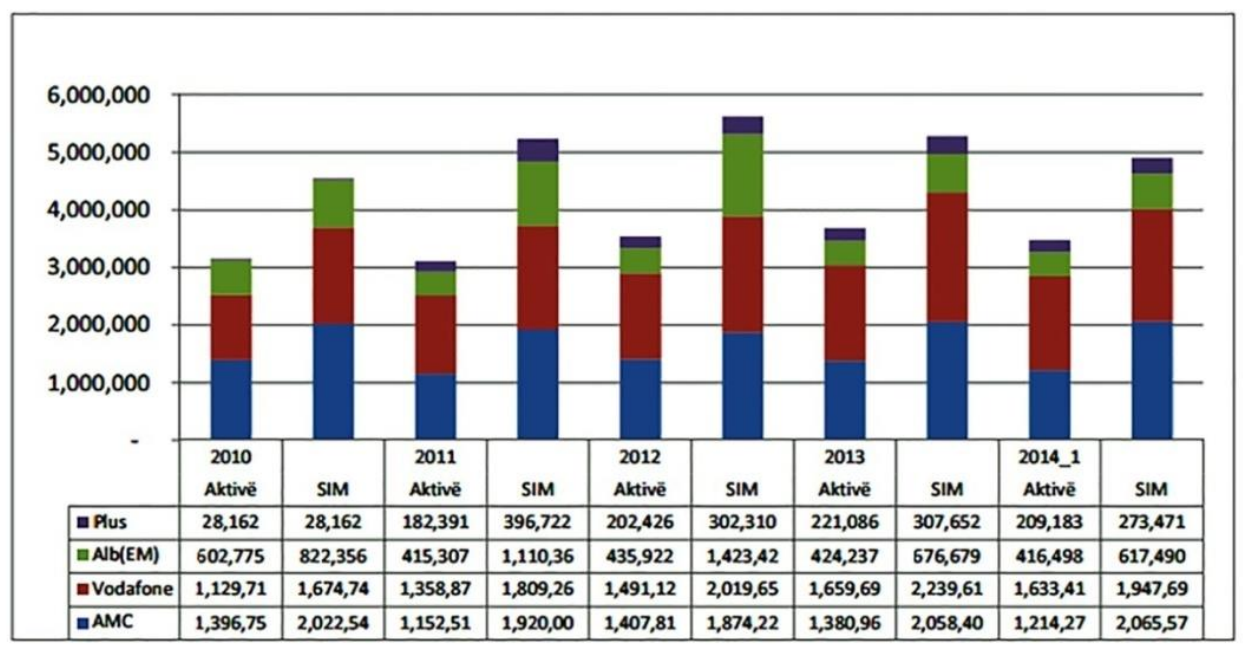

Figure 2 Number of fixed telephony subscribers in 2000-2014_1 


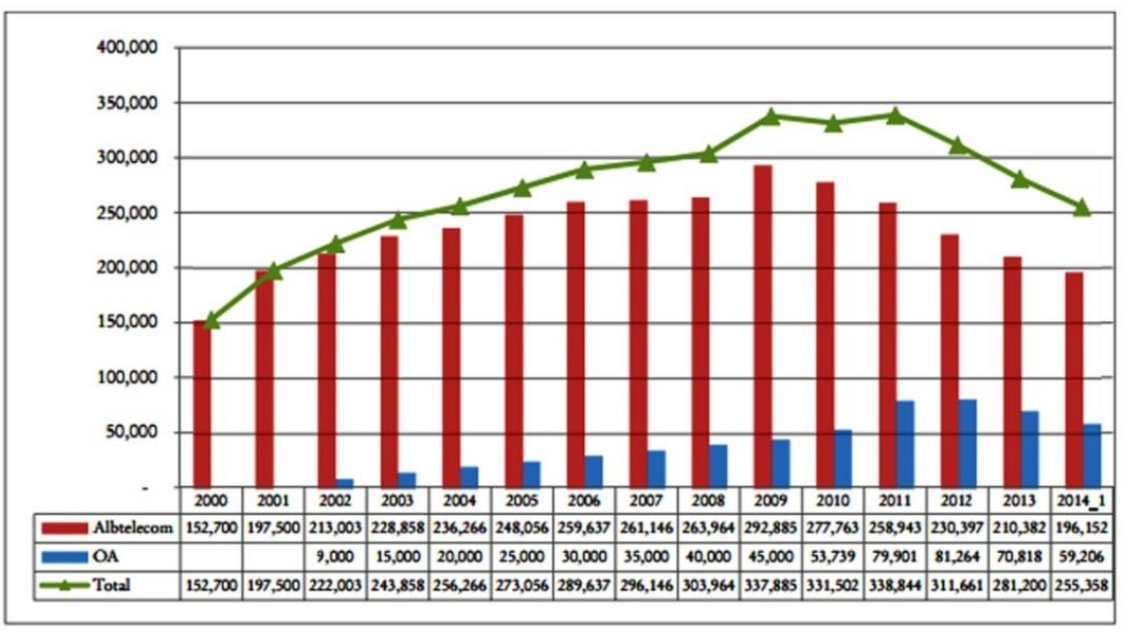

Figure 3 Subscribers with broadband access via fixed and $3 \mathrm{G}$ networks

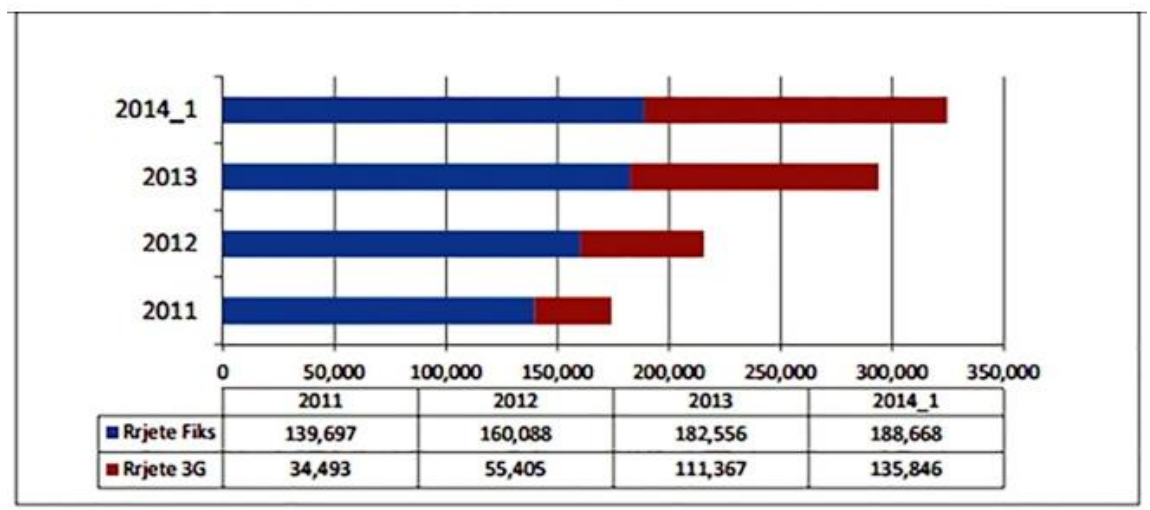

Figure 4 Albania's classification in the index of electronic government services in the South_East European countries.

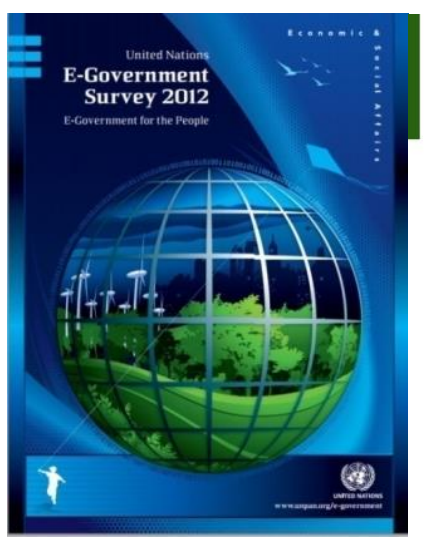

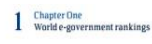
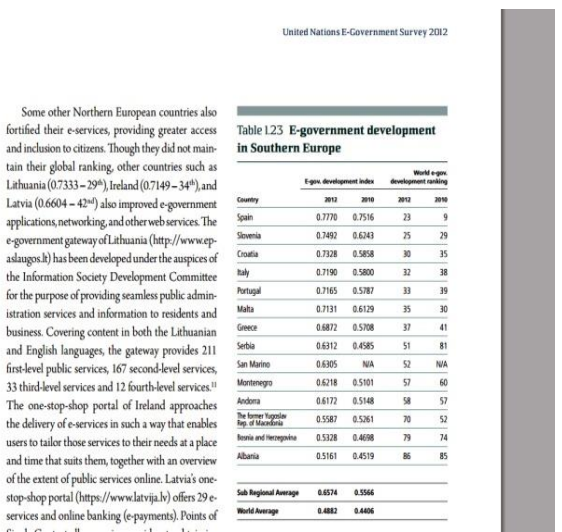